\title{
Understanding the Nexus of R\&D, Innovation and Economic Growth in Nigeria
}

\author{
Yusuf O. Akinwale ${ }^{1}$, Abolaji D. Dada ${ }^{1}$, Adekemi J. Oluwadare ${ }^{1}$, Olalekan A. Jesuleye ${ }^{1} \&$ Willie O. Siyanbola ${ }^{1}$ \\ ${ }^{1}$ National Centre for Technology Management, Obafemi Awolowo University, Ile-ife, Nigeria \\ Correspondence: Yusuf O. Akinwale, National Centre for Technology Management, Obafemi Awolowo \\ University, Ile-ife, Nigeria. Tel: 234-805-522-9353. E-mail: yemiiakinwale@yahoo.com
}

Received: August 30, 2012

Accepted: October 9, $2012 \quad$ Online Published: October 19, 2012

doi:10.5539/ibr.v5n11p187

URL: http://dx.doi.org/10.5539/ibr.v5n11p187

\begin{abstract}
R\&D and Innovation activities, which lead to technological progress, are considered as important factors contributing to stable and continuous economic growth. Total Factor Productivity accounts for the proportion of economic growth that is not captured by labour and capital inputs, and is measured by R\&D and innovation in this paper. The paper investigates the impact of R\&D and innovation, labour and capital on economic growth in Nigeria using Least Square Method. The result of the thirty one (31) years (1977-2007) reviewed shows that Gross Expenditure on R\&D (GERD) has significant impact on economic growth. The coefficient of R\&D which is negatively related to economic growth implies that it is not enough to increase spending on $\mathrm{R} \& \mathrm{D}$ and innovation when there are weak institutions, high corruption practices, low interaction between the academia and the industry, uncoordinated industrial clusters, among others. The result also shows that both labour and capital are directly related to economic growth, though the former plays a significant role while the latter does not. This paper concludes that government must be committed to R\&D and innovation funding, developing strong institutions, enhancing the academia-industrial linkage as well as implementing a workable science, technology and innovation policy in order to bolster and diversify the economy. Government should also provide various fiscal incentives for the industrial firms in their various clusters so as to encourage them to engage in R\&D and innovation activities, either through reverse engineering or inventing new ones, as this will not only lead to economic growth but also raise the global competitiveness of Nigeria.
\end{abstract}

Keywords: Research and Development, innovation, Total Factor Productivity, economic growth, technology progress

\section{Introduction}

Science, Technology and Innovation (STI) play vital roles in wealth creation and transformation in any society. Wealth can be distributed in the society only when it is first generated through the application of new technology for industrial development (Nigam, 1986). More than 50\% of the wealth created in developed countries emanated from technology which is typically a product of Research and Development (R\&D) (Lawrence \& Lau, 1996; Siyanbola, 2008). Technological transformation in countries such as the United States of America, China, France, United Kingdom, India, and South Korea has undoubtedly contributed significantly to the listings of these countries among the top 20 economies in the world. These technological transformations can be linked to high-level R\&D activities and innovation in the afore-mentioned countries. R\&D, leading to creation of new goods, new processes and new knowledge, is a major source of technical change (Guellec \& van Pottelsberghe, 2001). R\&D activities also entail the creation of new knowledge and the absorption of existing technology, which further leads to a reduction in the existing cost of production and an improvement in the quality of products.

Nigeria government has a national agenda of becoming one of the top 20 economies in the world by the year 2020. However, the gross domestic expenditure on R\&D as a percentage of GDP as at 2007 was 0.2 (African Innovation Outlook [AIO], 2010). To be relevant in the $21^{\text {st }}$ century, Nigeria needs to build sound technological infrastructure, strong STI capability and effective funding mechanism, and implement her STI policy to transform the economy into a modern one by the year 2020. It is therefore imperative to examine whether the contribution of R\&D and innovation will make an impact on economic growth in Nigeria. However, estimating how much investment in R\&D and innovation has contributed to economic growth is hard because it involves 
many complex data and methodological issues (Chung, 2010). One of the widely used approaches in capturing the impact of R\&D on economic growth is the concept of Total Factor Productivity (TFP). TFP is referred to as the variable which accounts for effects in aggregate output not caused by inputs. Comin (2006), explained TFP as the portion of output not explained by the amount of inputs used in production.

This paper therefore examines the impact of R\&D and innovation on economic growth with the central focus on Total Factor Productivity. Section two focuses on the literature review and the overview of R\&D and innovation in Nigeria, while methodology adopted and data analysis are discussed in section three. The last section concludes the paper and recommendations are made for government and policy makers.

\section{Literature Review}

This section presents the diverse views of different authors on R\&D and economic growth. Solow (1957) derived estimates of United States (US) total factor productivity between year 1909 and 1949. He concluded that technical change (usually referred to as residual) was responsible for the majority of economic growth in US within that period. There are other studies during that period such as Abramovitz (1957), Kendrick (1956), among others which suggested between $80 \%$ - 90\% contribution of technical change to aggregate productivity. Griliches and Clark (1984) presented the results of a study on productivity growth and R\&D in the 1970s using data on narrowly defined "business units" within a firm. The data used were drawn from the PIMS (Profit Impact of Market Strategy) project of the Strategic Planning Institute (SPI) in USA and the results showed that a significant relationship exists between R\&D and the growth of productivity. In the study, the duo estimated a marginal product or rate of return of about $18 \%$ in cases where TFP was used as the dependent variable. Cameron (1996) surveys the empirical evidence on the link between innovation and economic growth. He considered a number of measures of innovation, such as R\&D spending, patenting, and innovation counts, as well as the pervasive effect of technological spillovers between firms, industries, and countries. The paper concluded that innovation makes a significant impact on economic growth and that there are significant spillovers between countries, firms and industries, and to a lesser extent from government-funded research.

Also, Kim (2011) investigated the contributions of R\&D stock to economic growth using the R\&D-based Cobb-Douglas production function during the years 1976-2009 in South Korea. He asserted that R\&D activities generate the most efficient methods to raise competitiveness in the corresponding economy, which ensure stable and continuous economic growth. Based on the empirical results, the traditional production factors - labour and capital - contribute about $65 \%$ to economic growth. The contribution ratio of the total R\&D stock to economic growth is about $35 \%$. The study also showed that public and private R\&D stocks account for economic growth of about $16 \%$ and $19 \%$, respectively.

Comin (2006) asserted that since TFP is the fraction of output not explained by the amount of inputs used in production, then its level is determined by how efficiently and deeply the inputs are utilized in the production activities. The study established that TFP growth is usually measured by the Solow residual based on certain conditions such as neoclassical production function, perfect competition in factor markets and accurate measures of the growth rates of inputs. He confirmed that TFP plays a critical role in economic fluctuations, economic growth and cross-country per capita income differences. Hence, TFP is strongly correlated with output and hours worked. Helpman (1997) concluded that the TFP of a country depends not only on how much R\&D it does, but also on how much R\&D is done in other countries with which it engages in trade and investment based on the cross-country survey carried out. His study emphasized that the precise estimates of the impact of R\&D is still difficult to capture due to non-availability of data and some unsettled methodological issues. However, there exists significant cross-country links that are driven by foreign trade and investment.

Guellec and van Pottelsberghe (2001) carried out a panel data analysis of 16 OECD (Organization for Economic Cooperation and Development) countries between 1980 and 1998 on the impact of R\&D on productivity. They classified $R \& D$ into domestic business $R \& D$, public $R \& D$ and foreign business $R \& D$. The study presented estimates of the contribution of technical change to Multiple Factor Productivity growth in the countries surveyed. Their model was based on a simple Cobb-Douglas production function. The result showed that there is an increasing return on investment in $R \& D$. Increased spending on $R \& D$ enabled businesses to reap internal economies of scale, set up networks, and benefit from each other's discoveries. It also denoted a capability to absorb domestic knowledge generated by other firms and/or industries. It can also be deduced from the results that there is high level of spill-over technologies within the countries which are only beneficial to those countries that already have absorptive capacity. The study recommended that government should provide the right framework for encouraging solid relationships between public and private research, so that knowledge could flow more easily between the two sectors. The study concluded that the three forms of R\&D, as stated above, are 
important for productivity and economic growth of any nation.

\subsection{Research and Development}

Research and Development (R\&D) refers to "creative work undertaken on a systematic basis in order to increase the stock of knowledge, including knowledge of man, culture and society, and the use of this stock of knowledge to devise new applications" (OECD, 2002). R\&D is often scientific or directed towards developing particular technologies and is frequently carried out as corporate or governmental activity. The Frascati Manual on Research and Experimental Development (OECD, 2002) categorizes R\&D under three main activities: Basic research, applied research and Experimental Development. Basic research entails experimental or theoretical work undertaken primarily to acquire new knowledge of the underlying foundation of phenomena and observable facts, without any particular application or use in view. Applied research is an original investigation undertaken in order to acquire new knowledge but directed primarily towards a specific practical aim or objective, while Experimental Development involves systematic work, drawing on existing knowledge gained from research and/or practical experience, which is directed to producing new materials, products or devices, to installing new processes, systems and services, or to improving substantially those already produced or installed. The availability of necessary $R \& D$ infrastructure helps nations to develop new technologies, creates opportunities and improves their technological positions on the global scene (Charpie, 1970).

\subsection{Innovation}

The idea that innovation fosters economic growth is broadly shared and accepted among economists worldwide. In recent times, innovation has been a key driver of economic growth in most advanced countries, albeit it is still poorly understood by many countries (Becheikh, Landry \& Amara, 2006). All over the world, innovation has become a yardstick for measuring competitive advantage and a major determinant of enhanced productivity at both the firm and national levels (Federal Ministry of Science and Technology [FMST], 2010).

Innovation is defined as the implementation of a new or significantly improved product (good or service), or process, a new marketing method, or a new organisational method in business practices, workplace organisation or external relations (OECD, 2005). This broad definition of innovation encompasses a wide range of possible innovations. Innovations are generally categorized as product innovations, process innovations, marketing innovations and organisational innovations. A product innovation is the introduction of a good or service that is new or significantly improved with respect to its characteristics or intended uses. This includes significant improvements in technical specifications, components and materials, incorporated software, user friendliness or other functional characteristics. A process innovation is the implementation of a new or significantly improved production or delivery method. This includes significant changes in techniques, equipment and/or software. The implementation of a new marketing method involving significant changes in product design or packaging, product placement, product promotion or pricing is referred to as marketing innovation. An organisational innovation is the implementation of a new organisational method in business practices, workplace organisation or external relations.

\subsection{Overview of $R \& D$ and Innovation in Nigeria}

The history of Research and Development in Nigeria can be traced to the establishment of a National Council for Scientific and Industrial Research (NCSIR) in 1964, following an international conference on the Organisation of Research and Training in Africa (FMST, 2010). The Council's mandate was narrow and as such had structural weakness which made its function ineffective and inefficient. However, with the assistance of UNESCO experts, four research councils were established after the Civil war in 1970. These were:

\section{Agricultural Research Council of Nigeria (ARCN)}

\section{Medical Research Council of Nigeria (MRCN)}

\section{Natural Sciences Research Council of Nigeria (NSRCN)}

\section{Industrial Research Council of Nigeria (IRCN)}

In 1986, the first National Policy on Science and Technology (S\&T) was launched. The policy identified that S\&T-related activities in the country had been carried out without well defined national direction. The commercialisation of research results was restricted to publishing them in journals. In 1999, a revised version of National Policy on S\&T was prepared for a 25 -year time frame with 5 years revision interval. The policy emphasized Nigeria's commitment to the creation of an independent, integrated and self sustaining economy. Some achievements were recorded during this period in many aspects of Agriculture but it could be said that the policy lacked effective implementation mechanism as well as evaluation and monitoring strategies. Sanni, Ilori, 
Opaleye and Oyewale (2001) further concluded that the inadequacy of national S\&T output can be attributed to defects in the formulation and implementation of S\&T policy.

The 2003 Science and Technology Policy review was based on the global change in S\&T Policy and also due to the emerging frontiers of knowledge. The new policy was thus reviewed to, among others, stimulate initiative and creativity in the S\&T community, and encourage the mobility of scientists and researchers to network and explore the best opportunities and alternatives in the country and abroad for use and improvement of their competence. However, in 2011, the policy was reviewed to incorporate Innovation and the policy has since been referred to as the Science, Technology and Innovation (STI) policy.

Major constraints which have been facing the implementation of S\&T Policy in Nigeria include inadequate funding, coupled with lack of continuity or consistency. Despite the huge contribution of R\&D and innovation to economic growth in the developed and emerging nations, Nigeria is yet to fully harness R\&D to boost its economy. In 2010, oil and gas accounted for approximately $97 \%$ of the country's foreign exchange and $76 \%$ of the total government revenue (Central Bank of Nigeria [CBN], 2010). Before the discovery of oil, Nigeria was among the major exporters of cocoa, palm oil and other agricultural products. Agriculture accounted for more than $60 \%$ of the country's GDP and export earnings. R\&D and innovation have been given little attention by the government in the past with the belief that the revenue from the petroleum products is sufficient for the nation. This has adversely affected the manufacturing, services and other trading sectors as productivity in these sectors fell drastically in favour of the oil and gas sector.

However, with the rate of depletion of natural resources in so many naturally endowed countries and the extent of global competitiveness, it has become imperative for developing countries like Nigeria to embrace R\&D and innovation as a vital tool for accelerating their socio-economic development (Siyanbola, 2011). It is becoming increasingly clear that R\&D and innovation are not only important determinants of a country's level of development but also enhance its international competitiveness and its position in the world economy.

Nigeria's R\&D expenditure was US\$ 582 million (PPP) in 2007, and this figure represents $0.2 \%$ of the national GDP (AIO, 2010). The country was ranked 127th out of 139 countries assessed in the 2011 Global Competitiveness Report and has no university in the world's top 500. Gross Expenditure on R\&D (GERD) is relatively insignificant when compared with the R\&D expenditure profiles of the advanced countries of America, Europe and some parts of Asia. Consequently, the national R\&D capabilities have been undermined by underfunding. There also exists a weak interaction among the key actors of the national innovation system in the country (Aju, 1994; Oyebisi, Ilori \& Nassar, 1996; Oyewale, 2003; Oyewale, Dada \& Siyanbola, 2008). Industrial firms in Nigeria have not been making effective use of the inventions/research results of Nigerian research institutes, as they tend to have little to do with these institutes. As a result of little R\&D activities in the business sector in Nigeria unlike developed nations, government funds over $95 \%$ of the R\&D activities with developmental research accounting for only $26.1 \%$ of the entire research activities in Nigeria (AIO, 2010). Having realised some of these challenges, the current government plans to provide an effective funding mechanism as well as the governance system and strategies for achieving appropriate funding of R\&D activities in Science, Technology and Innovation (STI). The government recently approved the National Research and Innovation Fund (NRIF) which is a product of the new national STI policy tailored towards economic transformation and the development of STI in the Nation.

Technology which is usually achieved through R\&D is the engine of economic growth, and technology-based development can occur only with concerted efforts to revitalize education, develop personnel, and create integrated industries (Egbogah, 2007). This can be evidenced by the contribution of ICT to the standard of living of the Nigerians since year 2000 as well as the enormous benefits that the recently launched Communication Satellite (NIGCOMSAT-1R) will generate.

\subsection{Industrialisation in Nigeria}

In further discussing the relationship between R\&D, Innovation and Economic growth, it is important here to discuss the industries within which these activities take place. The role of industrialisation in economic development cannot be overemphasized, with cluster-based initiatives gradually emerging as the tool for industrial development and competitiveness. A major characteristic of industrial clusters is the relatedness of firms which are co-located in a specific region. Porter (2003) defines clusters as 'geographically proximate group of interconnected companies, suppliers, service providers and associated institutions in a particular field, linked by externalities of various types'. The health and strength of clusters help to enhance the innovativeness of firms (Porter, 1990). Firms situated within specific clusters can achieve higher levels of innovation which creates economic benefits, thereby enhancing the development of the economy as a whole. 
Different administrations since 1960 have introduced several policies targeted at making industrialisation the engine of economic growth in Nigeria. Most of these policies have, however, suffered poor implementation mainly due to lack of political will on the part of the government, inconsistency of political administrations, and inadequacy of policies (Amobi, 2006; Iwuagwu, 2011). There are several industrial clusters scattered across the six geo-political zones in Nigeria. These clusters include Information and Communications Technology (ICT) cluster in Lagos state, Leather processing cluster in Kano and Abia states, Textile cluster in Ogun, Kano, Abia and Kaduna states, Wood and Furniture cluster in Edo and Oyo states and the automotive parts cluster in Nnewi, among others. These clusters have been identified to experience specialised supplies of raw materials and components, increase in sector-specific skills, inter-firm cooperation and promotion of innovation and collective learning (Amobi, 2006). Most of these clusters, being Small and Medium Enterprise (SME), however face various challenges which range from poor infrastructure to low international competitiveness. Enhancing the potential for growth and exports of industrial clusters in Nigeria requires adequate attention from the government. Government policies must be designed to create and sustain the right environment for the clusters to thrive.

\section{Methodology and Data Analysis}

The Ordinary Least Squares method (OLS) of multiple regressions is adopted in estimating a specified model. OLS determines the nature of relationship between selected variables (Brooks, 2008). This seeks to examine whether changes in one variable leads to changes in other variable(s). Linear Multiple Regression is employed as a result of more than one independent variable that is involved. This statistic is necessary when the objective is to investigate the possibility that movement in the dependent variable is caused by independent variables. Gross expenditure on $R \& D$ (GERD) is the measure of $R \& D$ and innovation (in measuring its contribution to the economy) and the Gross Domestic Product at constant basic price (Real GDP) is adopted for economic growth. GERD is an important indicator of a nation's innovative capacity and a measure of future productivity and growth. GDP refers to the market value of all final goods and services produced within a country in a given period, usually a year.

The data used in this paper were obtained from secondary sources. The data were collated from different sources such as annual statistical bulletin of the Central Bank of Nigeria (CBN), National Bureau of Statistics (NBS), Federal Ministry of Finance and African Innovation Outlook (AIO) 2010. The paper focused on time series data between 1977 and 2007. The data for GERD are difficult to measure in developing nations and actually not available in Nigeria as at the period of this study except for the data obtained from the African Innovation Outlook which put the estimated GERD as a percentage of GDP at 0.2 in year 2007. Assumption is then made to cover the entire scope of the study by putting the estimated GERD as a percentage of Nominal GDP at 0.1 and 0.2 for $1977-2000$ and 2001-2007 respectively. The conventional growth function provides that output is expressed as a function of labour and capital, with the assumption of a constant level of technological know-how (Solow, 1956). This can be shown as:

$$
\mathrm{Q}=f(A, K, L)
$$

Where $\mathrm{Q}=$ Output, $\mathrm{L}=$ Labour, $\mathrm{K}=$ Capital/Investment, and $\mathrm{A}=$ Constant Level of Technology

This is also express in Cobb-Douglas model as adapted from Barro (1990):

$$
Y=A(t) K^{\beta 1} L^{\beta 2}
$$

Once natural $\log$ is introduced $\beta 1$ and $\beta 2$ represent elasticity of capital and labour respectively.

The Neoclassical growth model as stated in equation (1) dominated economic thought for many decades because it does a good job in explaining much of what we observe in the world and because of its mathematical importance. The Solow growth model was also known as the exogenous model because it professed technology as an exogenous factor which determines growth. One of the basic assumptions of the Solow model is the diminishing returns to labour and capital and constant returns to scale as well as competitive market equilibrium and constant savings rate. However, what is crucial about the Solow model is the fact that it explains the long run per capita growth by the rate of technological progress, which comes from outside the model (Odularu \& Okonkwo, 2009). Nonetheless, by the late 1980s, dissatisfaction with the theory had risen on both theoretical and empirical grounds. Neoclassical growth theory attributes long-run growth to technological progress but leaves unexplained the economic determinants of that technological progress. In other words, technological progress was exogenised.

This gave birth to endogenous growth theory and the concept of Total Factor Productivity (TFP). This theory was developed as a result of some flaws noticed in the neoclassical growth theory. Romer $(1986,1990)$ takes 
knowledge as an input in the production function and aims at explaining the long run growth by taking technical progress or productivity growth as endogenous variable. Some of the assumptions of the theory are:

- Increasing returns to scale because of positive externalities.

- Knowledge or technical advances are non-rival goods.

- Human capital (knowledge, skills and training of individuals) and the production of new technologies are essential for long run growth.

- Private investment in $R \& D$ is an important source of technological progress.

This theory also stated that a higher level of savings and capital formation leads to greater investment in human capital and R\&D. Hence, the model predicts that the economy can grow forever as long as it does not run out of new ideas or technological advancement. Also, diffusion of technology might lead to convergence of nations (Lucas, 1988). This means that poor countries may improve their economic growth by imitating the technology of the richer countries. Thus, technological progress through $R \& D$ is treated as one of the explanatory (endogenous) variables that can cause economic growth.

In this case, $R \& D$ and innovation (proxied by Gross Expenditure on $R \& D$ ) is introduced as TFP which accounts for the technological growth in an economy alongside other variables. The model also considered gross fixed capital formation and labour force as part of the independent variables that could contribute to economic growth. The reduced form of the model can be written as:

$$
R G D P=f(G E R D, G F C F, L A B F)
$$

Where RGDP $=$ Real Gross Domestic Product

GERD $=$ Gross Expenditure on Research and Development

$\mathrm{GFCF}=$ Gross Fixed Capital Formation

$\mathrm{LABF}=$ Labour Force

In order to reduce or remove the stochastic error term, the log linear form for equation (3) is expressed as:

$$
\operatorname{lrgd} p=\beta 0+\beta 1 \lg \text { erd }+\beta 2 \lg f c f+\beta 3 \text { llabf }+U t
$$

Where $\beta 0=$ Constant factor,

$\beta_{\mathrm{t}=1 \mathrm{to3}}=$ Coefficient of lgerd, lgcfc and llabf respectively

$\mathrm{Ut}=$ error term

The model explains the relationship between Real GDP which is the dependent variable and GERD (proxy for TFP), GFCF and LABF which are the independent variables. There is need to estimate empirically the magnitude of this effect and also to analyze the nature of the relationship between the variables that measure $R \& D$ and innovation activities and economic growth. One of the relationships will show the impact of $R \& D$ on economic growth and the others will show the impact of capital stock and labour force on economic growth. Three hypotheses formulated to examine the impact of the three independent variables on economic growth are stated below:

$$
\begin{array}{lll}
\text { Hypothesis } 1 & \text { Ho: } \boldsymbol{\beta}_{\mathbf{1}}=\mathbf{0} ; & \mathrm{H}_{1}: \boldsymbol{\beta}_{\mathbf{1}} \neq \mathbf{0} \\
\text { Hypothesis } 2 & \text { Ho: } \boldsymbol{\beta}_{\mathbf{2}}=\mathbf{0} ; & \mathrm{H}_{1}: \boldsymbol{\beta}_{2} \neq \mathbf{0} \\
\text { Hypothesis } 3 & \text { Ho: } \boldsymbol{\beta}_{\mathbf{3}}=\mathbf{0} ; & \mathrm{H}_{1}: \boldsymbol{\beta}_{\mathbf{3}} \neq \mathbf{0} \\
\text { Hypothesis } 4 & \text { Ho: } \boldsymbol{\beta}_{\mathbf{1}}, \boldsymbol{\beta}_{2}, \boldsymbol{\beta}_{\mathbf{3}}=\mathbf{0} ; & \mathrm{H}_{1}: \text { At least one } \boldsymbol{\beta}_{\mathbf{k}} \neq \mathbf{0} \text { where } \mathbf{k}=\mathbf{1 , 2} \text { and } \mathbf{3}
\end{array}
$$

From Hypothesis 1 to 3, Ho which represents the Null hypothesis states that each independent variable has no significant impact on economic growth respectively while the Alternative hypothesis $\mathrm{H}_{1}$ means that the independent variable has a significant impact on economic growth respectively. Meanwhile, Ho in Hypothesis 4 shows that the independent variables are not jointly significantly important in explaining changes in economic growth while $\mathrm{H}_{1}$ in Hypothesis 4 illustrates that at least some variables in the model are jointly significant in explaining the economic growth.

E-views7 statistical package is used to run the multiple linear regressions of the model with white heteroskedasticity-consistent standard errors \& covariance. Appendix 1 shows real GDP (RGDP), Gross Expenditure on R\&D (GERD), Gross fixed capital formation (GFCF) at current market value and stock of labour force (LABF) which are the data from which the regression results were obtained. The result is shown in Table 1. 
Table 1. Regression Results for the Study

Method: Least Squares with white heteroskedasticity-consistent standard errors \& covariance

\begin{tabular}{|c|c|c|c|c|}
\hline Dependent Variable & LRGDP & & & \\
\hline Sample & 1977: 2007 & & & \\
\hline Observations & 31 & & & \\
\hline Variable & Coefficient & Std error & t-statistic & $\operatorname{prob}(\mathrm{p}$-value $)$ \\
\hline LGERD & -0.873521 & 0.341292 & -2.559452 & 0.0164 \\
\hline LGFCF & 0.132557 & 0.203617 & 0.651014 & 0.5205 \\
\hline LLABF & 9.793161 & 2.411742 & 4.060617 & 0.0004 \\
\hline $\mathrm{C}$ & -18.71 & 7.833267 & -2.389675 & 0.0241 \\
\hline R-Squared & 0.789 & & & \\
\hline Adjusted R-Squared & 0.766 & & & \\
\hline F-statistic & 33.76 & & & \\
\hline Prob(F-statistic) & 0.0000 & & & \\
\hline
\end{tabular}

Source: Authors' Analysis (2012).

The level of significance adopted to test the hypotheses is $5 \%$. Though the primary variables of interest are real GDP and GERD, the model was extended to include other variables in order to capture labour and capital as stated in the endogenous growth model.

The result of the regression shows that approximately $78.9 \%$ of the changes in economic growth can be attributed to GERD, GFCF and LABF which connotes that the independent variables explained variations in the dependent variable by $78 \%$. Given the p-value of the F-statistic $(0.00005)$, it can be deduced that at least some of the independent variables play a role in explaining economic growth of the country (at $5 \%$ level of significance). The result also shows that TFP elasticity of output is -0.87 and has a significant impact on economic growth with the probability value of 0.0164 (at $5 \%$ level of significance). This implies that increase in GERD, though plays a significant role in explaining economic growth, may also lead to reduction in economic growth if there is corruption, poor governance and political will, weak institutions and poor interaction among the elements of the National System of Innovation in the country. If there is no link between the academia/researchers that produce research outputs and the industries that use such outputs, no matter the extent of R\&D, it will not be able to yield positive outcomes on the economy. The regression results also show that capital and labour have positive elasticity relationship to economic growth with coefficients 0.13 and 9.7 respectively. This means that the Nigerian economy improves faster with increase in labour force (both in skills and quantity) than increase in capital. This may not be unconnected with employment generation which increases the disposable income and purchasing power of households; hence, increasing national aggregate demand and reducing the level of crime rate in Nigeria. The p-values of capital formation and labour are 0.5205 and 0.004 respectively, which depict that while labour force has a significant impact on economic growth, capital formation does not have a significant impact at $5 \%$ level of significance. The insignificant impact of the capital formation to economic growth may be as a result of the low level of investment on state-of-the-art machines and equipments by the Nigerian government and local investors. Thus, government should encourage the importation and local development of the required sophisticated machines through various local and international policies.

\section{Conclusion and Recommendations}

Many emerging nations such as China, South Korea, and Singapore, have given special attention to their technological development. This is due to the effect of technological efforts which led to increase in their economic growth. Nigerian government has also started making a lot of effort to improve its expenditure on R\&D and innovation as well as improving the weak national system of innovation. This study is focused on the period between 1977 and 2007 using gross fixed capital formation, labour force and Gross expenditure on R\&D as a proxy for R\&D and innovation. The result shows that GERD plays a significant role on economic growth but an inverse coefficient is also observed between them. This implies that it is not enough to increase spending on $R \& D$ and innovation when there are weak institutions, high corruption practices, low interaction between the academia and the industry, poor coordination system, among others in the country. The nature of the industrial activities in the six geo-political regions in Nigeria will determine whether buying technology from the developed world will be more appropriate for some regions or developing indigenous technology. The result also shows that labour and capital have positive relationship with economic growth though while the former has a significant impact on economic growth, the latter does not. Once government increases its spending on R\&D and innovation, it will have a significant impact on the economy by driving it towards growth. The expenditure on 
R\&D and innovation will directly and indirectly have impact on both labour force and capital which will further improve the economy. The limitation to this study is in the area of non-availability of data on R\&D and innovation in Nigeria.

This paper recommends that Nigerian government should create an enabling environment with strong institutions, improved interactions between the academics and the companies that use research outputs, sound rule of law and governance among others, so as to translate the increase in its spending on R\&D and innovation to economic growth. This will lead to technology spillovers within the industries in the country and at the same time prepare the country to absorb international spillovers from abroad which could boost the economy and enhance her global competitiveness. Government must also be committed to adopt some of the foreign strategies to build human capacity and develop a workable STI framework so as to propel the manufacturing sector into a dynamic future. Government intervention to mitigate the obstacles faced by SME clusters in Nigeria is vital, so also is the introduction and sustenance of various economic policies by the government such as fiscal incentives in order for the private companies to be encouraged to engage in reverse engineering and R\&D activities. This is because private sector involvement effectively complements public sector activities in carrying out the nature of technological development that will enable the country to meet its target as one of the 20 largest economies by the year 2020. In addition, policy implementation on STI should be geared towards encouraging developmental research, as against basic research, and purchasing of international technologies that can drive economic growth.

\section{References}

African Innovation Outlook. (AIO). 2010. Research and Experimental Development. Pretoria, Johannesburg: South Africa. pp. 35-76. Retrieved from: http//:www.nepadst.org

Aju, A. (1994). Industrialisation and Technology Innovation in an African Economy. Regional Centre for Technology Management, Lagos: Ibadan, Oluseyi Press.

Amobi, I. C. (2006). Unleashing of Industrial Clusters for Growth and Prosperity in South East Nigeria. Proceedings from the Enugu Forum Seminar. Nigeria, October, 2006.

Barro, R. (1990). Government Spending in a Simple Model of Endogenous Growth. Journal of Political Economy, 98, 103-125. http://dx.doi.org/10.1086/261726

Becheikh, N., Landry, R., \& Amara, N. (2006). Lessons from innovation empirical studies in the manufacturing sector: A systematic review of the literature from 1993-2003. Journal of Technovation, 26, 644-664. http://dx.doi.org/10.1016/j.technovation.2005.06.016

Brooks, C. (2008). Introductory Econometrics for Finance (2nd ed.). London: Cambridge University Press. http://dx.doi.org/10.1017/CBO9780511841644

Cameron, G. (1996). Innovation and Economic Growth. Centre for Economic Performance. Discussion Paper, No. 277.

Central Bank of Nigeria. (2008). Statistical Bulletin.

Central Bank of Nigeria. (2010). Statistical Bulletin.

Charpie, R. A. (1970). Technological Innovation and the International Economy. In M. Goldsmith (Ed.), Technological Innovation and the Economy. London: Wiley-Interscience.

Chung, S. (2010). Innovation, Competitiveness and Growth: Korean Experiences. Science and Technology Policy Institute (STEPI), Korea.

Comin, D. (2006). Total Factor Productivity. New York University and NBER Working Paper.

Egbogah, E. (2007). The Role of Technology in National Development. Talent and Technology, 1(2).

Federal Ministry of Science and Technology (FMST). (2010). The National Policy for Innovation in Nigeria. A Paper presented at the National Workshop on Strengthening Innovation and Capacity Building in the Nigerian Manufacturing Sector. July 20-21, 2010.

Griliches, Z., \& Clark, K. (1984). Productivity Growth and R\&D at the Business Level: Results from the PIMS Data Base (pp. 393-416). University of Chicago Press.

Guellec, D., \& van Pottelsberghe, B. (2001). R\&D and Productivity growth: Panel Data Analysis of 16 OECD countries. OÉCD Economic Studies No. 33. http://dx.doi.org/10.1787/652870318341

Helpman, E. (1997). R\&D and Productivity: The International Connection. NBER Working Paper, No. 6101.

Iwuagwu, O. (2011). The Cluster Concept: Will Nigeria's New Industrial Development Strategy Jumpstart the 
Country's Industrial Takeoff? Afro Asian Journal of Social Sciences, 2(2.4). Quarter IV.

Kim, J. (2011). The Economic Growth Effect of R\&D Activity in Korea. Economy Journal, 12, 25-44.

Lawrence, L., \& Lau, L. (1996). Sources of Long-Term Economic Growth. In R. Landau \& L. A. Stanford (Eds.), The Mosaic of Economic Growth. Stanford University Press.

Lucas, R. (1988). On the Mechanics of Economic Development. Journal of Monetary Economics, 22, 3-42. http://dx.doi.org/10.1016/0304-3932(88)90168-7

Nigam, J. K. (1986). Structuring of Research Institutes to promote integration with industry. In M. D. Nengu (Ed.), R\&D institutes and local industry interaction: An international perspective (pp. 265-271). WAITRO.

Odularu, G., \& Okonkwo, C. (2009). Does energy Consumption contribute to economic performance? Empirical evidence from Nigeria. East-West Journal of Economics and Business, 12(2), 43-79.

Organization for Economic Cooperation and Development (OECD). (2002). Proposed Standard Practice for Surveys on Research and Experimental Development (6th ed.) (p. 30). OECD.

Organization for Economic Cooperation and Development (OECD). (2005). Guidelines for Collecting and Interpreting Innovation Data (3rd ed.) (pp. 46-51). A joint publication of OECD and EuroStat.

Oyebisi, T., Ilori, M., \& Nassar, M. (1996). Industry-academic relations: an assessment of the linkages between a university and some enterprises in Nigeria. Technovation, 16(4), 203-209. http://dx.doi.org/10.1016/0166-4972(95)00049-6

Oyewale, A. A. (2003). Evaluation of the Interactions among the Key Components of Science and Technology and Innovation System in Nigeria. (Unpublished doctoral dissertation). Obafemi Awolowo University, Ile-Ife, Nigeria.

Oyewale, A. A., Dada, A. D., \& Siyanbola, W. O. (2008). Issues on Inventions, Research and Development Outcomes and Patent Generations in Nigerian Universities. Proceedings of 17th International Conference on Management of Technology (IAMOT, 2008). Dubai United Arab Emirate. April 6-10.

Porter, M. E. (1990). The Competitive Advantage of Nations. Harvard Business Review, 71-91.

Porter, M. E. (2003). The Economic Performance of Regions. Regional Studies, 37(6\&7), 549-578.

Romer, P. (1986). Increasing Returns and Long run Growth. Journal of Political Economy, 94, 1002-1037. http://dx.doi.org/10.1086/261420

Romer, P. (1990). Endogenous Technological Change. Journal of Political Economy, 98, S71-S102. http://dx.doi.org/10.1086/261725

Sanni, S. A., Ilori, M. O., Opaleye, A. O., \& Oyewale, A. A. (2001). Nigeria's technology policy: is it adequate in the globalizing world? Technovation, 21, 237-243. http://dx.doi.org/10.1016/S0166-4972(00)00044-4

Siyanbola, W. O. (2011). Progress Report on Nigeria's National Science, Technology and Innovation Policy. (PowerPoint slides). A paper presented at the Experts' meeting on Science, Technology and Innovation Policy Review. Nigeria.

Solow, R. (1956). A Contribution to the Theory of Economic Growth. Quarterly Journal of Economics, 70, 65-94. http://dx.doi.org/10.2307/1884513 


\section{Appendix}

Appendix 1

\begin{tabular}{|c|c|c|c|c|}
\hline Year & GERD (in million) & RGDP (in million) & GFCF (in million) & LABF (in million) \\
\hline 1977 & 31.52 & $31,520.34$ & $9,420.60$ & 24.31 \\
\hline 1978 & 34.54 & $29,212.35$ & $9,386.30$ & 25.05 \\
\hline 1979 & 41.97 & $29,947.99$ & $9,094.50$ & 25.78 \\
\hline 1980 & 49.63 & $31,546.76$ & $10,841.20$ & 26.50 \\
\hline 1981 & 47.62 & $205,222.06$ & $12,215.00$ & 27.17 \\
\hline 1982 & 49.07 & $199,685.25$ & $10,922.00$ & 27.83 \\
\hline 1983 & 53.11 & $185,598.14$ & $8,135.00$ & 28.48 \\
\hline 1984 & 59.62 & $183,562.95$ & $5,417.00$ & 29.15 \\
\hline 1985 & 67.91 & $201,036.27$ & $5,573.00$ & 29.87 \\
\hline 1986 & 69.15 & $205,971.44$ & $7,323.00$ & 30.63 \\
\hline 1987 & 105.22 & $204,806.54$ & $10,661.10$ & 31.42 \\
\hline 1988 & 139.09 & $219,875.63$ & $12,383.70$ & 32.26 \\
\hline 1989 & 216.80 & $236,729.58$ & $18,414.10$ & 33.11 \\
\hline 1990 & 267.55 & $267,549.99$ & $30,626.80$ & 33.98 \\
\hline 1991 & 312.14 & $265,379.14$ & $35,423.90$ & 35.03 \\
\hline 1992 & 532.61 & $271,365.52$ & $58,640.30$ & 36.10 \\
\hline 1993 & 683.87 & $274,833.29$ & $80,948.10$ & 37.20 \\
\hline 1994 & 899.86 & $275,450.56$ & $85,021.90$ & 38.32 \\
\hline 1995 & 1933.21 & $281,407.40$ & $114,476.30$ & 39.46 \\
\hline 1996 & 2702.72 & $293,745.38$ & $172,105.70$ & 40.63 \\
\hline 1997 & 2801.97 & $302,022.48$ & $205,553.20$ & 41.83 \\
\hline 1998 & 2708.43 & $310,890.05$ & $192,984.40$ & 43.04 \\
\hline 1999 & 3194.01 & $312,183.48$ & $175,735.80$ & 44.26 \\
\hline 2000 & 4582.13 & $329,178.74$ & $268,894.50$ & 45.49 \\
\hline 2001 & 9450.17 & $356,994.26$ & $371,897.90$ & 46.84 \\
\hline 2002 & 13824.76 & $433,203.51$ & $438,114.90$ & 48.19 \\
\hline 2003 & 16974.06 & $477,532.98$ & $429,230.00$ & 49.56 \\
\hline 2004 & 22822.13 & $527,576.04$ & $456,970.00$ & 50.94 \\
\hline 2005 & 29144.48 & $561,931.39$ & $462,350.20$ & 56.17 \\
\hline 2006 & 37129.19 & $595,821.61$ & $470,600.10$ & 58.93 \\
\hline 2007 & 41314.64 & $634,251.14$ & $473,200.40$ & 61.25 \\
\hline
\end{tabular}

Source: Authors' compilation from Federal Ministry of Finance, NBS and CBN Statistical Bulletin (2008-2010). 